\title{
Gaudium et spes, Globalization and the Developing World
}

\author{
Shaji G. Kochuthara
}

\section{Introduction}

Though the term "globalization" was in use before Vatican II, as far as its current meaning is concerned, the concept is of later origin (in 1970s). Thus, in Gaudium et spes (further only GS) or in the other documents of Vatican II, we do not find references to "globalization" as we speak of it today. However, GS visualizes the need of an interconnected world, where all are related to each other in fraternity and solidarity. In this paper, drawing inspiration from GS and subsequent Church documents, we shall analyse globalization, especially from the perspective of the developing world. Many of the concrete references given will be from the Indian situation, but similar situations can be found in other parts of the world.

GS reflects on the meaning of human existence and activity in this world. Salvation comes not by fleeing from the world, but by engaging the world inspired by faith. Although GS deals with economic, social, cultural, national and international life, it is not basically a socio-politicaleconomic document. Its vision is basically theological. The Church is above all trying to scrutinize "the signs of the times and of interpreting them in the light of the Gospel", guided by the conviction that "faith throws a new light on everything, manifests God's design for man's total vocation, and thus directs the mind to solutions which are fully human". ${ }^{2}$ So, when we look into GS and subsequent documents, we are not looking primarily for new sociological and economic theories, but we are trying to understand and interpret the world and the developments in it in the light of faith.

\section{Globalization}

It is difficult to define globalization. In his book Globalization and its Discontents, ex-World Bank economist Joseph Stiglitz defines it as the removal of barriers to free trade and the closer integration of national economies. Stiglitz believes that globalization can be a good thing but his career in one of the global institutions has also shown him firsthand the devastating effects

Gaudium et spes 4. Further only GS and section number.

2 GS 11. 
these institutions' policies can have on poor people in developing countries. ${ }^{3}$ However, many do not consider globalization as a mere economic phenomenon though it may be the most visible dimension. Globalization is also a social, cultural and political phenomenon. N. R. Narayana Murthy, the co-founder and executive chairman of Infosys, defines globalization at two levels:

"At the macro level, it is about frictionless flow of capital, services, goods and labour across the globe. It is also about global sharing of ideas, knowledge and culture. It is about creating a shared concern and plan for global issues like poverty, AIDS and environment... At the microeconomic or firm level, it is about sourcing capital from where it is cheapest, sourcing talent from where it is best available, producing where it is most efficient and selling where the markets are, without being constrained by national boundaries."

On the one hand, considering globalization as evil in itself or as the cause of all the problems in this world seems to come from an overly pessimistic view. On the other hand, presenting globalization as a panacea for all the problems that the world faces and the only solution at hand seems to be too optimistic.

In general, globalization is welcomed by the elite and the corporate sector in the developing countries like India. Especially the new generation youth who are employed in IT, management and allied sectors are strong proponents of globalization, whereas many of those employed in agriculture, the poor and those working for social welfare are its opponents.

\section{Globalization and Economic Development}

\section{Can a developing country like India survive without globalization?}

Narayana Murthy holds that India has to embrace globalization and integrate better with global markets. His arguments can be summarised as follows:

The only way to eradicate poverty in India is by creating jobs. The number of the unemployed in India is estimated around 250-300 million. Every year, about 35-40 million new job seekers are added. Moreover, more than $65 \%$ of the population are in rural areas and their primary livelihood is from agriculture, which adds just $26 \%$ of the GDP. Showing the prospective growth rate in the agricultural sector, he argues that this also means that by 2017, 100 to 120 million people have to be moved from agriculture to other sectors. In short, every year 45 to 50 million people have to find new jobs. According to him, the solution is to create jobs in the low-tech manufacturing sector, which demands considerable increase in export. This demands enhancing interactions with global markets. According to Murthy, this is what globalization is all about. ${ }^{5}$

After independence (1947), India had adopted a semi-socialist economic policy. In 1991, a new economic policy of liberalization was adopted, giving more freedom for economic activity and imparting global linkage, leading to privatization and globalization. The positive effects of this new policy are seen in an increase in GDP growth rate, foreign direct investment, foreign exchange

Cf. STIGLITZ, Globalization and its Discontents, London: Penguin Books, 2002, p. ix.

4 N. R. Narayana MURTHY, Making Globalization Work for India, Mumbai: Nani A. Palkhivala Memorial Trust, 2007, p. 14.

Cf. ibid, pp. 14-20. 
and outsourcing. India is often presented as one of the fastest growing economic powers. It is predicted that by 2030 India may become the second largest economy in the world and by 2050 the largest. However, there are also negative effects of liberalization and globalization, namely, growing unemployment, widening disparities, neglect of agriculture and widespread poverty. ${ }^{6}$

The percentage of people living below the poverty line may give an idea of the continuing poverty and growing disparity. According to the Reserve Bank of India statistics, the percentage of those below the poverty line was 35.97 in 1993-94, 26.10 in 1999-2000 and 21.80 (based on the $\mathrm{MRP}=$ Mixed Recall Period) and 27.50 (based on the URP=Uniform Recall Period). ${ }^{7}$ The statistical data provided by different agencies do not agree with each other, and the criterion for deciding the poverty line is varied and confusing. The income criterion to determine the poverty line in India is based on 2004-05 data where it is stated that all India's level of minimum income for rural and urban areas for a person per month should be Rs. 356.30 and Rs. 538.60 respectively (at present 1 USD is about 65 Indian rupees). ${ }^{8}$ However, according to a 2005 World Bank estimate, $41.6 \%$ of the total Indian population falls below the international poverty line of USD 1.25 a day. ${ }^{9}$ Recently, the criterion to define the poverty line resulted in a heated debate. The Indian Planning Commission's affidavit to the Supreme Court of India states that adjusting for inflation, the poverty line for an urban person is Rs 32.5 per day per person and for a rural person it is Rs 29.3 per day per person. This raised an outcry from many. Based on these poverty lines, the Planning Commission estimates that there are 407.4 million persons below the poverty line in 2010-11. ${ }^{10}$ Whatever be the criterion for calculation, it is also evident that a good number of people live just above the poverty line. Moreover, we need to take into account opinions that more than $70 \%$ of the people are poor. ${ }^{11}$

Poverty existed in India even before the onset of liberalization and globalization. But, what is pertinent to consider is that the growth in GDP in the recent decades, an argument in favour of globalization, is not reflected in the life of a big number of people. This points to the widening gap between the poor and the rich. Similarly, the claim that globalization creates more jobs is not accepted by many. It is pointed out that in recent years the number of unemployed persons has increased. ${ }^{12}$

Agricultural sectors have suffered a lot due to globalization. The agricultural land of small farmers is taken to create Special Economic Zones (SEZ), without giving them sufficient compensation

6 (c) Presentation Supreti TYAGI, "New Economic Policy", (on-line) at http://www.scribd.com/doc/13709734/New-Economic-Policy-1991, accessed on November 20, 2015.

7 ○ RESERVE BANK OF INDIA, Table 162: Number and Percentage of Population below Poverty Line, (on-line) at http://www.rbi.org. in/scripts/PublicationsView.aspx?id=13750, accessed on November 20, 2015.

8 (C) Shankar CHATTERGEE, "Estimation of Rural Poverty: A Discussion with Reference to India", paper presented at WYE City Group on Rural Development and Agriculture Household Income, at FAO Headquarters, Rome, June 11-12, 2009, (on-line) at http:// www.fao.org/fileadmin/templates/ess/pages/rural/wye_city_group/2009/paper_3_1_chatterjee_ITALY.doc, accessed on November $20,2015$.

9 () THE WORLD BANK, Overview (on-line) at http://www.worldbank.org/en/country/india/overview, accessed on November 20, 2015.

10 Cf. () Kirit PARIKH, “The Poverty Line Debate”, Hindustan Times (2 April, 2012), (on-line) at http://www.hindustantimes.com/ News-Feed/ColumnsOthers/The-poverty-line-debate/Article1-752547.aspx, accessed on April 2, 2012.

11 For example, N. C. Saxena, National Advisory Council member, holds that more than $70 \%$ of Indians are poor. Cf. ( ) "About 70 percent of India si poor: NAC member", Zeenews March 25, 2012 (on-line) at http://zeenews.india.com/business/news/economy/about-70-percent-of-india-is-poor-nac-member_44536.html, accessed on November 20, 2015.

12 "Unemployment rate increases in India", The Times of India Jun 23, 2013 (on-line) at http://articles.timesofIndia.Indiatimes.com/201306-23/India/40146190_1_urban-India-urban-women-rural-women, accessed on November 20, 2015. 
and without rehabilitating them. Though in places like Nandigram ${ }^{13}$ in West Bengal the farmers have succeeded to resist forceful acquisition of their land, in many other places they have failed. Since subsidies are reduced or removed, many are unable to continue farming. Take for example, the thousands of farmers who committed suicide in the last few years. It is said that in the state of Gujarat alone, the state which is often presented as the model of development and where the present prime minister of India was the chief minister for a long time, more than 16000 farmers committed suicide in the last 10 years. ${ }^{14}$ Add to this the thousands of farmers who committed suicide in Bihar, Uttar Pradesh and other states.

One of the major premises of the Washington Consensus' view of globalization is the role of foreign investment. According to this, 'freeing up' markets promotes economic growth by attracting international investors. Foreign businesses are supposed to bring with them technical expertise and access to foreign markets and financial sources, thus creating new employment opportunities. However, there is a flipside of this, namely, large global corporations often destroy local competition and home-grown industries. For example, Coca-Cola and Pepsi have wiped out many local soft drink manufacturers all over the world. If competition is the only norm, the small scale industries and firms do not succeed, rather they are annihilated. This only adds to the number of poor, though the accumulation of wealth by the big firms will appear in the increase of the GDP.

In his paper "Transcending the Washington View of Development"15 Thomas Pogge shows how the official poverty statistics issued by the World Bank regarding the schedule towards achieving the first Millennium Development Goal (MDG1), which claims that poverty has been reduced, does not reflect the reality. According to him, on the contrary, poverty and undernourishment has only increased. He also says that in the last twenty-one years since the end of the Cold War, roughly 380 million people have died from poverty-related causes. "Despite all of the proclaimed ideals, our seemingly lofty declarations, poverty and its concomitant human rights deprivations persist on a massive scale. They persist even while global average income is increasing and the world on the whole is doing quite well." Pogge holds that the enormous extent of the disparities that have built up during the globalization period in the distribution of global household income is responsible for this. In 2005, the top 5\% of the world's population received $46.36 \%$ of the global household income, the next $20 \%$ almost the same proportion (that is, the top quarter had $90.34 \%$ of the global household income), whereas the other three quarters together had only $9.66 \%$; the poorest quarter had only $0.78 \%$. Substantiated by statistical data, Pogge argues that only the richest $5 \%$ has gained in the globalization period. ${ }^{16}$

13 At Nandigram in West Bengal, the Communist Party of India Marxist (CPIM) - led government decided to expropriate 10000 acres $\left(40 \mathrm{~km}^{2}\right)$ of land from the farmers for a Special Economic Zone (SEZ) to be developed by the Indonesian based Salim Group for industrialization. This was opposed by the farmers and this led to widespread violence and killing and rape of many by the police and allegedly by the CPIM party workers in March 2007. Finally the government was forced to abandon the project. It may be paradoxical that the CPIM, who claims to be protectors of farmers, acted against the farmers and let loose violence on them. Eventually the CPIM, which ruled West Bengal for about three decades, lost the assembly election in 2011.

14 Cf. Mallika SARABHAI, "Modi and His Mayajaal", The Week, October 30, 2011, p. 98.

15 Thomas POGGE, “Transcending the Washington View of Development”, in Towards a Strong Global Economic System: Revealing the Logic of Gratuitousness in the Market Economy, ed. Saju CHACKALACKAL, Bangalore: Dharmaram Publications, 2013 , pp. 73-101.

16 Cf. ibid, pp. 84-86. 


\section{Globalization and Economic Solidarity}

Globalization offers great potentialities for development through trade and financial ties between nations and distribution of capital and wealth. Advancement in technology, communication media and removal/relaxing of international trade barriers has made a global community possible. Though this growing interconnectedness of peoples around the globe is a very welcome sign, sharp inequalities, exploitation, domination, oppression and corruption continue in different forms. Inequalities between developed countries and developing countries shoot up. Even within the developed countries, inequalities augment. ${ }^{17}$ As GS has pointed out, "While an immense number of people still lack the absolute necessities of life, some, even in less advanced areas, live in luxury or squander wealth". 18

In the beginning, many people in countries like India were apprehensive that globalization is a form of economic colonialism and hence exploitative. People in developed countries were rather enthusiastic about globalization. But now a good number of people in the developed countries do not seem to be so enthusiastic about it, especially since the economic recession. Millions of people in the developed countries have lost their jobs as many firms shifted their production units to other countries where labour is cheap. To be added to this are millions of jobs outsourced. Arguably, a number of people in the countries where production units are opened and jobs are created benefit. But, often the multinationals enter into deals with the local governments, to get their own terms accepted. Thus, though many people in the developing countries benefit, the profit of the multinational firms has increased enormously and this growth is without any solidarity, since they are not accountable to anyone either in their home countries or in the countries where they have opened their units. As a result, the development is largely the development of big firms. This lack of solidarity reinforces inequalities, injustice, exploitation and subsequently poverty and suffering. Unless globalization attends to this, it will turn into a "globalization of indifference" as Pope Francis has repeatedly warned. ${ }^{19}$

Imbalances and inequality in development make the poor poorer. Take, for example, the city of Bangalore, the IT hub of India, the city in which I live. Tens of thousands of people have found jobs in software companies and BPO which offer them very good salaries. But, a good number of people are employed in low-income sectors; many do not have a secure job or any job at all. There are a number of people who earn more than 100000 Rupees per month. But, in the same city, there are hundreds of thousands of people who earn just 2000 Rupees. Often that is the income for the whole family. With the economic boom in the city, food, housing, education, healthcare, etc. have become very costly. In short, the so called development in the globalization period has not improved the life of the poor; rather, their life is rendered more miserable.

All these make clear that free trade alone is not enough to ensure social justice. "The economy needs ethics in order to function correctly - not any ethics whatsoever, but an ethics which is people-oriented." ${ }^{20}$ The World Commission on the Social Dimension of Globalization underscores that the governance of globalization must be based on universally shared values and respect for

17 Pogge argues that the globalization period has seen a massive increase in intra-national inequality in nearly all countries, including those that have achieved high rates of national economic growth. Ibid., pp. 90-91.

18 GS 63.

19 Cf. FRANCIS, Laudato si' 52.

20 BENEDICT XVI, Caritas in veritate, 45 . Further only CV and section number 
human rights. It acknowledges that, "Globalization has developed in an ethical vacuum, where market success and failure have tended to become the ultimate standard of behaviour, and where the attitude of 'the winner takes all' weakens the fabric of communities and societies."21 Any economic system and developmental programmes should recognise the "centrality of the human person". ${ }^{22}$ As GS has emphasized, "The fundamental finality of this production is not the mere increase of products nor profit or control but rather the service of man, and indeed of the whole man...". ${ }^{23}$

Only if globalization is based on the principle of solidarity, it will ensure justice and distribution of wealth. Otherwise, it will only intensify and perpetuate injustice on the global level. GS has underscored the need of sharing in justice and charity: "God destined the earth and all it contains for all men and all peoples so that all created things would be shared fairly by all mankind under the guidance of justice tempered by charity". ${ }^{24}$ Though this was said before the onset of globalization, this vision of sharing in justice is especially relevant in the context of globalization, because "peace for all of us comes from the justice of each of us." ${ }^{25}$ Injustice done anywhere in the globalized world will adversely affect peace, harmony and development in any other part of the world.

The "Kingdom of God" envisions a human society that lives in solidarity, a human society that lives as a family where God is the Father of all and all are brothers and sisters. "The development of peoples depends, above all, on a recognition that the human race is a single family working together in true communion..." ${ }^{26}$ Competitiveness and profit should not alienate the market from solidarity with the human family. Only a "civilization of love" can ensure this. ${ }^{27}$

\section{Corruption, Globalization and Neo-Liberalism}

I am not trying to argue that corruption is the invention of globalization. But, globalization has given new faces to corruption. A study published in November 2010 by Global Financial Integrity (GFI), an international advocacy group, says that corruption in India has increased considerably after liberalization. According to its report, between 2002 and 2006, due to corruption the loss to the government was 16 billion dollars (720 billion rupees) per year. ${ }^{28}$ As Arundhati Roy points out, "Twenty years ago, when the era of 'liberalisation, privatisation and globalisation' descended on us, we were told that public sector units and public infrastructure needed to be privatised because they were corrupt and inefficient. We were told the problem was systemic. Now that nearly everything has been privatised, when our rivers, mountains, forests, minerals, water supply, electricity and communications systems have been sold to private corporations, we find that corruption has grown exponentially, the growth rate of corruption has surpassed everything we could possibly imagine."29

21 WORLD COMMISSION ON THE SOCIAL DIMENSION OF GLOBALIZATION, A Fair Globalization: Creating Opportunities for All, Geneva: ILO Publications, 2004, no. 37, p. 7.

$22 \mathrm{CV} 47$.

23 GS 64

24 GS 69.

25 JOHN PAUL II, "From the Justice of Each Comes Peace for All”, Message of His Holiness Pope JOHN PAUL II for the Celebration of the World Day of Peace, 1 January 1998, \# 7, (on-line) at http://www.vatican.va/holy_father/john_paul_ii/messages/peace/documents/ hf_jp-ii_mes_08121997_xxxi-world-day-for-peace_en.html, accessed on November 20, 2015. 
In recent years, one of the areas of widespread corruption in India has been the acquisition of land, especially for the multinational corporations. Special privileges and exemptions to multinational corporations may be needed to attract them. But, when this is at the cost of the life of the poor, denying their basic human rights, it is to be reconsidered. Moreover, often, behind such deals and agreements, politicians and bureaucrats get crores (tens of millions) of rupees for easy deals according to the terms and conditions of these corporations. Thus, corruption betrays the interests of the ordinary people, especially the poor. Speaking at Life After Capitalism at the "World Social Forum 2003," Porto Alegre, Brazil, January 27, 2003, organised by Znet, Arundhati Roy said, "As the disparity between the rich and the poor grows, the fight to corner resources is intensifying. To push through their 'sweetheart deals', to corporatize the crops we grow, the water we drink, the air we breathe, and the dreams we dream, corporate globalization needs an international confederation of loyal, corrupt, authoritarian governments in poorer countries to push through unpopular reforms and quell the mutinies." ${ }^{\text {30 }}$

Thus, one of the effects of globalization can be said to be the globalization of corruption and its reinforcement. Its impact can be seen also in India. This is yet another proof that an economy without ethics, in which profit and success at any cost are the only norms, is disastrous and does not lead to real development.

\section{The Impact of Globalization on Cultures}

Though globalization is a beautiful ideal, we find resistance to it in different parts of the world, from different cultures. In some places this resistance has been violent. Why does this happen? As mentioned above, globalization has implications for the socio-economic, political, cultural and religious life of people. Globalization has an inherent tendency to bring homogeneity, not only in business and trade worldwide, but also in socio-cultural and religious life. Here, the culture of the dominant or influential groups and countries becomes normative; they are presented as ideal or global. Consequently, the indigenous cultures, especially of the poor and weaker countries, feel threatened. Many cultures consider globalization as a form of neo-colonialism, as another attempt of conquering and destroying their cultures by the West. That is, though on the one hand many may welcome the benefits of globalization, they feel threatened by the hidden cultural invasion by the dominant players of globalization. Influence on local values and cultures may happen through consumer goods and life-style. Many in India seem to fear that globalization is a threat to the values of Indian culture, especially those regarding family and sexual life and ethics. This fear is heightened by the increasing reach of the global media, entertainment and tourism industry. "The increasing reach of the global media, entertainment, and tourism industry is placing stress on traditional cultures and on the values, sense of identity and solidarity of local communities." ${ }^{31}$ For example, if you ask an Indian why divorce rate or promiscuity or pre-marital sex is on the increase in India in recent years, usually the immediate reply would be that it is the influence of the Western culture. ${ }^{32}$ This fear of cultural invasion is also one of the reasons

30 Arundhati ROY, “Confronting Empire”, Outlook India.com, January 30, 2003, (on-line) at http://www.outlookindia.com/article. aspx?218738\#.T3rEnhKYxIU, accessed on March 4, 2012.

31 WORLD COMMISSION ON THE SOCIAL DIMENSION OF GLOBALIZATION, A Fair Globalization, no. 299 , p. 68.

32 Personally I do not agree with this opinion. The West also had a culture of high sexual morality and family life, thanks to Christianity. The new culture that took hold of the Western society from the 1950s is not typically Western. It is a culture neither of the West nor of the East, but a culture created mainly by the media and the new market tyrants, motivated by the ideology of profit at any cost. It is true that this new culture began in the West, but it reaches everywhere. Shaji George KOCHUTHARA, "Sexuality: Changing Per- 
behind the fight against Westernization/Americanization in the Islamic world and the increasing fundamentalist tendencies in many cultures and countries. To sell the products creating a sense of need in the consumers, to spread their values and life style which promote their business and to get easy access to societies, the proponents of globalization need to create a homogeneous culture, ignoring and even destroying the local cultures and their traditional value systems. Globalization, if it has to win the confidence of the people, has to avoid this colonial tendency: "The trust among people bound by common values and culture is the 'glue' which binds local institutions to undertake joint actions. This social capital is essential for development. Globalization can both strengthen and weaken social capital." 33

"Cultural levelling and indiscriminate acceptance of types of conduct and life-styles" are harmful to the "profound significance of the culture of different nations, of the traditions of the various peoples, by which the individual defines himself in relation to life's fundamental questions." ${ }^{34}$ The vision should not be of a global homogeneous culture, but a global community that accommodates the multitude of local cultures. It is pertinent to listen to what Pope John Paul II has said in this regard: "Globalization must not be a new version of colonialism. It must respect the diversity of cultures which, within the universal harmony of peoples, are life's interpretive keys. In particular, it must not deprive the poor of what remains most precious to them, including their religious beliefs and practices, since genuine religious convictions are the clearest manifestation of human freedom." ${ }^{35}$

I am not proposing that each culture is perfect in itself or that no culture should learn anything from others. Each culture has its own richness, as well as defects. To be enriched, each culture should be open to other cultures to learn from them. However, it should not be through domination or the levelling of cultures by external agencies. Respecting the uniqueness of cultures, globalization can strengthen the cultures through healthy dialogue rooted in solidarity.

\section{Globalization in Solidarity with Ecology}

An important aspect of solidarity is the solidarity with the nature. In the reckless search for profit, often the ecological balance of the planet and the limitedness of its resources are ignored. Unscrupulous exploitation of natural resources, destruction of the forests, flora and fauna without considering the needs of future generations, and technological developments that cause a burden on the future generations are in fact counterproductive. We are already experiencing the disastrous effects of global warming caused by the damage done to ecology. It will not be just to hold globalization responsible for the whole destruction done to ecology. The ecological crisis has roots in the development models and policies adopted in the last few decades. However, globalization has heavily intensified the trends that endanger ecology and has introduced new elements. Often, the multinational companies which manage to influence and even dictate government policies easily ignore the havoc done to ecology and future generations. Rapid growth of the economy, which is the demand and need of the market, requires rapid and major expansion of infrastructure and resource extraction. To be added to this is the encouragement

spectives", in Moral Theology in India Today. The DVK Workshop on Moral Theology, Bangalore: Dharmaram Publications, 2013, pp. $522-523$.

33 WORLD COMMISSION ON THE SOCIAL DIMENSION OF GLOBALIZATION, A Fair Globalization, no. 310 , p. 70.

34 CV 26.

35 JOHN PAUL II, “Address to the Pontifical Academy of Social Sciences” (27 April, 2001), \# 4: AAS 93 (2001), p. 600. 
of wasteful consumption, especially by the rich, without which the present model of the market cannot survive. This results in projects and processes with negative consequences for the ecology. Liberalization of trade has led to a rapid increase in exploitation of natural resources to earn foreign exchange, which has serious consequences for the traditional livelihoods and ecological balance in different regions. Norms to safeguard the ecology are sacrificed to make a 'friendly' climate for investment. ${ }^{36}$ I shall give a few instances of the havoc done to ecology in the globalization period:

Export of marine products from India has risen from 139419 tonnes in 1990-1991 to 602835 tonnes in 2008-2009. It can be said to be a sign of development and economic gain. But at what cost? At the cost of serious ecological damage and disruption of the livelihoods of traditional fisher-folk and farmers. Studies have revealed that the social and environmental costs of shrimp aquaculture were 3.5 times the earnings. Moreover, as more and more areas are converted to shrimp farming, local fish that are the staple food of the local people are eliminated. ${ }^{37}$

With the liberalization of imports, India has become a major importer of hazardous and toxic wastes from industrial countries. Import of metal wastes is in several millions of tonnes annually. The quantity of imported waste in the computer industry also has increased dramatically. About $70 \%$ of e-wastes found in recycling units of Delhi were those dumped by industrial countries into India. For example, a company named Attero got permission to import 8000 tonnes of e-waste in 2009. This does not mean that only multinational corporations are responsible for the ecological destruction in India. Indian companies (especially the influential ones) follow suit. Another area of concern is tourism. The number of domestic tourists has increased from about 140 million in 1996 to 527 million in 2007, and that of foreign tourists from 2.29 million to 5.08 million. ${ }^{38}$ Ecologically sensitive areas have been opened up for tourism. Moreover, a lot of construction, often violating all norms, have taken place in these areas, for creating a 'friendly' climate for investment in tourism industry. The recent flash floods in Uttarkhand, one of the North Indian states in the Himalayan region, in which thousands of people, mainly tourists/pilgrims, were killed is said to be a typical example of the disastrous effects of development in the name of pilgrimage/tourism without respecting ecology. ${ }^{39}$ Extensive areas of land, especially in rural and forest areas, have been given for mining to national and multinational corporations, leading to the destruction of agricultural land and forest. Several bills have been passed by the governments (both state governments and the central government) which allow them to acquire the land belonging to farmers and tribals.

Bangalore, the city where I live, was known as the "Garden City" of India. Even today many use that name, but we would doubt whether it deserves it any more. Many would say that it has become a garbage city. In the last 15 years, the population of the city has tripled. Consequently, the city suffers from air and water pollution, frequent traffic blocks, lack of open space, scarcity of water and so on. In 1961, Bangalore had 262 water bodies (lakes and tanks). During 1973-2007, there was a decline of water bodies by $70.69 \%$, most of it having taken place after 1992. Most of these water bodies were encroached on by big developers. Consequently, there is a decrease in depth of the ground water from 10-12 metres to 100-200 metres in the last 20 years. ${ }^{40}$

36 Ashish KOTHARI, “Globalization and Its Alternatives: A View from India”, Policy Matters (18 November, 2011), pp. 177-179.

37 Cf. ibid, pp. 182-183.

38 Cf. ibid, pp. 184-190.

39 Though the officially confirmed death toll is around one thousand, even many agencies, government officials and ministers have said that the real number of deaths could be between 10000 and 15000 .

40 Cf. Saji Mathew KANAYANKAL, "Where Do We G(row)o? A Critique on 'Development' from an Ecological and Ethical Perspective", in Moral Theology in India Today. The DVK Workshop on Moral Theology, ed. Shaji George Kochuthara, CMI, Bangalore: Dharmaram 
Evidently, these are not problems that India alone faces ${ }^{41}$ Unbridled competition and unscrupulous demands in the market lead the profit-motivated national and multinational corporations in any part of the world to the exploitation of natural resources and developmental works at the cost of the environment. However, the developing and poor nations are more severely affected. Globalization has given easy access to many multinational corporations to the developing and poor countries, where they are not constrained by standards and restrictions which they have to abide by in their home countries.

There is no doubt that we need development and a 'friendly' atmosphere for investment both by national and multinational corporations. To meet the growing demands and to compete with the global market, we also need to extract the natural resources available. The pertinent question would be, 'To what extent are we entitled to exploit the natural resources?' The answer depends on the sustainability of the ecological system, the genuine needs of human society, respect for the whole of nature and the needs of the present as well as future generations. Needs of the market and profit motive should not become the only criteria for the decisions to make use of the natural resources and development. There is a growing awareness that, "Respect for nature requires globalization to be ecologically sustainable, respecting the natural diversity of life on earth and the viability of the planet's ecosystem, as well as ensuring equity between present and future generations." ${ }^{.42}$ However, big business enterprises, which are motivated only by profit, together with corrupt politicians and officials ignore or violate the norms to safeguard the ecology, defeating the demands for sustainable development. "A development which is driven by greed, profit for the few and unbridled search for luxury, can only lead to the destruction of the environment and ultimately of humans themselves. Sustainable development takes account of environmental preservation." ${ }^{33}$

Pope Benedict XVI, in his encyclical Caritas in Veritate (further only CV) underscores that the developmental model of globalization should be aware of the fact that "Environment is God's gift to everyone, and in our use of it we have a responsibility towards the poor, towards future generations and towards humanity as a whole." ${ }^{.44}$

Two important concerns need to be mentioned here:

1. Solidarity and justice in the use and distribution of energy resources. CV points out that hoarding of non-renewable energy resources by some States, power groups and companies poses a grave obstacle to development in poor countries. CV urges the international community "to find institutional means of regulating the exploitation of non-renewable resources, involving poor countries in the process, in order to plan together for the future." ${ }^{35}$ It is also necessary to allot more funds for research into alternative sources of energy. Somehow many countries are still reluctant to invest in alternative energy sources. For example, even after the Fukushima Nuclear Plant tragedy following the earthquake on 11 March 2011, India is going forward with the plan of installing a number of nuclear power plants. There have been violent protests and

Publications, 2013, pp. 370-372.

41 For example, Randy J. C. ODCHIGUE narrates in his article the disastrous effects of indiscriminate mining in Philippines ("Recasting Christian and Cultural Resources for Environment and Sustainability”, Asian Horizons 6, 2 (2012), pp. 271-286. Similarly Finomo Julia AWAJIUSUK shows the degradation of the Niger Delta in recent years ("Genesis 1:26-28 - A Panacea for Environmental Degradation in Niger Delta, Nigeria", Asian Horizons 6, 2 (2012), pp. 248-260).

42 WORLD COMMISSION ON THE SOCIAL DIMENSION OF GLOBALIZATION, A Fair Globalization, no. 41 , p. 8.

43 Julian SALDANHA, SJ, "From Garden to City", Asian Horizons 6, 2 (2012), p. 266.

$44 \mathrm{CV} 48$.

45 CV 49. 
opposition from people in different places, as many would lose their habitat and livelihood. A typical example is the protest against the Koodankulam Power Plant in the state of Tamil Nadu. Many are apprehensive of the government's stubbornness in moving forward with such projects which cause a lot of damage to ecology for hundreds of years, while India has rich possibilities of making use of solar energy, wind energy and many other alternative sources. Many doubt whether the government is acting under the pressure of multinational groups and countries which install such huge power plants.

2. There is a "pressing moral need for renewed solidarity, especially in relationships between developing countries and those that are highly industrialized." 46 This solidarity also demands lowering of energy consumption from the part of the technologically advanced societies. Thomas Pogge points out that "wealthy countries contribute disproportionately to global pollution and yet they are allowed to enjoy the benefits of their polluting activities without compensating the poor who bear the brunt of the hazards of pollution." The poor are more vulnerable to health risks and dangers of climate change wrought by pollution. According to a Global Humanitarian Forum report, climate change causes $\$ 125$ billion in economic losses annually and 300000 deaths, of which $99 \%$ are in less developed countries. ${ }^{47}$ Solidarity requires that the developed nations, who are more responsible for the ecological damage bear in a proportionate manner the duty to compensate the damage done.

Solidarity with nature is in fact a global responsibility, "for it is concerned not just with energy but with the whole of creation, which must not be bequeathed to future generations depleted of its resources." ${ }^{\prime 8}$ Thus, solidarity with nature, besides being necessary for safe and healthy life today, implies a responsibility to the future generations.

\section{Globalization in Solidarity: a Few Proposals}

Globalization, if it should lead to real development, should be based on solidarity. Some of the proposals given by experts and world leaders in this regard may be helpful: ${ }^{49}$

1. Goods are to be shared without excluding anyone, without some hoarding them depriving others of the right to own them. This is one of the basic principles to ensure solidarity both in the international and intra-national levels. Fossil fuels and other non-renewable energy sources must be available to all nations, and unjust conditions in their production and distribution as well as arbitrary control over the regions rich in fuel deposits should be avoided.

2. International organizations should ensure just prices in trade. On essential goods subsidies are to be granted to poor nations. Similarly, poor sections within the nation are to be offered special subsidies. India, for example, had the system of granting subsidies to the poor. Since the introduction of the neo-liberal economic system, a number of subsidies were cut, especially under the pressure of IMF, WTO and other such organizations. It is claimed that subsidy system slows down the economic growth. However, it is paradoxical that to save big national and multinational companies, billions of rupees are written off. Often, the loss to the economy

46 Ibid; cf. JOHN PAUL II, Message for the 1990 World Day of Peace, no. 13.

47 Cf. Thomas POGGE, “Transcending the Washington View of Development”, p. 93.

48 CV 50

49 Here mainly we refer to some of the proposals given by Pope John PAUL II ("From the Justice of Each Comes Peace for All"), Oscar Andres Cardinal Rodriguez MARADIAGA ("The Catholic Church and the Globalization of Solidarity") and Thomas POGGE ("Transcending the Washington View of Development"). Please note that these or similar suggestions have been given by many experts and world leaders. 
in writing off the debt of the multi-million companies is much more than the subsidies granted to the poor. Preferential choice for the poor is an essential element of solidarity.

3. Specially to be mentioned is the obligation of the developed/industrialized countries to help the poorest. Moreover, in most cases this is a demand of justice of restitution, that is, a compensation for unjustifiable exploitation that many poor countries had to undergo in the past. Without generous assistance many such countries are unable to develop, as they still do not have the basic facilities and infrastructure. However, this assistance should not be on conditions which enslave them further.

4. Another important aspect of solidarity to be considered is regarding the external debt of the poor nations. Besides being backward, most of the poor nations are over-burdened by huge external debts which hinder their development. Moreover, these debts often compel them to accept exploitative conditions by rich nations and multi-national corporations, resulting in further underdevelopment. Unless the rich nations are willing to express their solidarity with the poor nations by cancelling their external debts (or at least writing off a considerable amount of it), practically it will be impossible for these nations to find the path of development. ${ }^{50}$

5. On the one hand, international organisations like UN, WTO, IMF, etc. are rendering great services in promoting peace and helping poor nations to progress. However, it is not rare that these organisations serve the interests of the rich and the powerful, sometimes even sidelining the needs and rights of the poor countries. These organisations have to become more representational, promoting justice to all, especially to the poor and weaker nations. The present structure of the UN Security Council cannot be considered democratic and hence needs to be reconsidered if its role and function has to be more effective. Similarly, the structure, membership and role in international bodies like WTO and IMF have to be reformulated, if they are to ensure solidarity with the poor and the weaker nations and peoples.

6. Patent regulations, which control the production of essential goods and their prices are to be reconsidered. ${ }^{51}$ This is acutely felt in the case of life-saving and essential medicines. While respecting the right of the inventor and producer for just profit, patent regulations should become sensitive to the needs of the people, especially of the poor. The historic ruling given by the Supreme Court of India, rejecting the petition by Novartis, and allowing the domestic companies to continue to make copycat versions of the drug Gleevec (Glivec), gives new hope to the poor. Whereas Gleevec may cost $\$ 70,000$ a year, the Indian generic versions cost less than $\$ 2,500$ a year. ${ }^{52}$ Evidently, such steps may be resisted by the multi-national corporations. But, they are necessary steps not to exclude the poor and the less privileged from the benefits of development.

7. Banking and credit systems have to become more accessible to the poor at affordable interest rates. Otherwise, their financial condition will be affected further and they will be marginalised from the benefits of economic progress.

8. Governments and NGOs should work together to ensure sustainable development, respecting the ecological conditions of the regions concerned. More investment should be made in developing alternative energy sources.

50 Cf. Rajesh MAKWANA, “Cancelling Third World Debt”, February 2006, (on-line) at http://www.stwr.org/aid-debt-development/ cancelling-third-world-debt.html, accessed on November 20, 2015.

51 To understand the extent to which patent regulations are misused for business motives, it is enough to consider the dispute over the patent for turmeric, a traditional spice and medicine used in India for thousands of years (cf. http://wwwl.american.edu/ted/turmeric $\mathrm{htm}$ ). Another example would be the dispute on patent for neemtree, a medicinal tree ( $\mathrm{cf}$. http://wwwl.american.edu/TED/neemtree. $\mathrm{htm}$ ). There were also attempts to obtain patents for Basmati rice and such traditional crops.

52 Cf. Gardiner HARRIS and Katie THOMAS, "Low-Cost Drugs in Poor Nations Get a Lift in Indian Court", New York Times (April 1, 2013), (on-line) at http://www.nytimes.com/2013/04/02/business/global/top-court-in-india-rejects-novartis-drug-patent.html?p agewanted=all\&_r=0, accessed on November 20, 2015; Sakthivel SELVARAJ, “Patent Justice”, The Hindu (April 7, 2013), (on-line) at http://www.thehindu.com/news/national/patent-justice/article4588895.ece, accessed on November 20, 2015. Thomas Pogge's article referred to above will be very helpful regarding the patent regulations regarding drugs. 
9. Globalization should respect the cultures and religions of people without imposing its 'homogeneous' culture.

\title{
8. Concluding Remarks
}

Although written a few years before the onset of globalization, Gaudium et Spes visualized a globalized world, where different peoples and nations are interconnected, based on the principles of justice, solidarity and sharing. Subsequent Church documents have continued this vision of globalization. In recent decades Papal documents, other official Church documents and theologians have addressed directly the reality of globalization.

As an ideal of interconnectedness of peoples, nations and cultures, globalization offers great possibilities. To realize this, globalization has to be rooted in the principle of solidarity, especially with the poor, the cultures and the ecology. Globalization should not be first about money, market or competition, but about people and their interconnectedness in a world which has to become one human family. Economic prosperity will lead to long-lasting peace and development only if it ensures justice to all.

\section{Gaudium et spes, Globalization and the Developing World}

\begin{abstract}
In its current meaning, the concept of "globalization" had its origin in 1970s. However, Gaudium et spes visualizes the need of an interconnected world, where all are related to each other in fraternity and solidarity. This paper, drawing inspiration from the constitution Gaudium et spes and subsequent Church documents, analzes globalization, especially from the perspective of the developing world. As an ideal of interconnectedness of peoples, nations and cultures, globalization offers great possibilities. To realize this, globalization has to be rooted in the principle of solidarity, especially solidarity with the poor, the cultures and the ecology. Globalization should not be first all of about money, market or competition, but about people and their interconnectedness in a world which has to become one human family. The human person must be at the centre of globalization. Economic prosperity will lead to long-lasting peace and development only if it ensures justice to all.
\end{abstract}

Keywords: globalization, developing world, India, Catholic social teaching, solidarity, Gaudium et spes

\section{Contact}

\section{Assoc. Prof. Shaji George Kochuthara}

Pontifical Athenaeum of Theology, Philosophy and Canon Law (Dharmaram Vidya Kshetram) 560029 Bangalore, India

kochuthshaji@gmail.com 